RESIDENT

\& FELLOW

SECTION

Section Editor

Mitchell S.V. Elkind,

MD, MS

Carsten Finke, MD

Masen Dirk Jumah, MD

Thomas Jöns, MD

Christoph J. Ploner, MD

Address correspondence and reprint requests to Dr. Carsten Finke, Department of Neurology, Charité-Universitätsmedizin Berlin, Campus Charité Mitte, Charitéplatz 1, D-10117 Berlin, Germany

carsten.finke@charite.de

\section{Teaching Video NeuroImages: \\ An endoscopic view of symptomatic palatal tremor}

回

\section{bilaterally (arrow)}

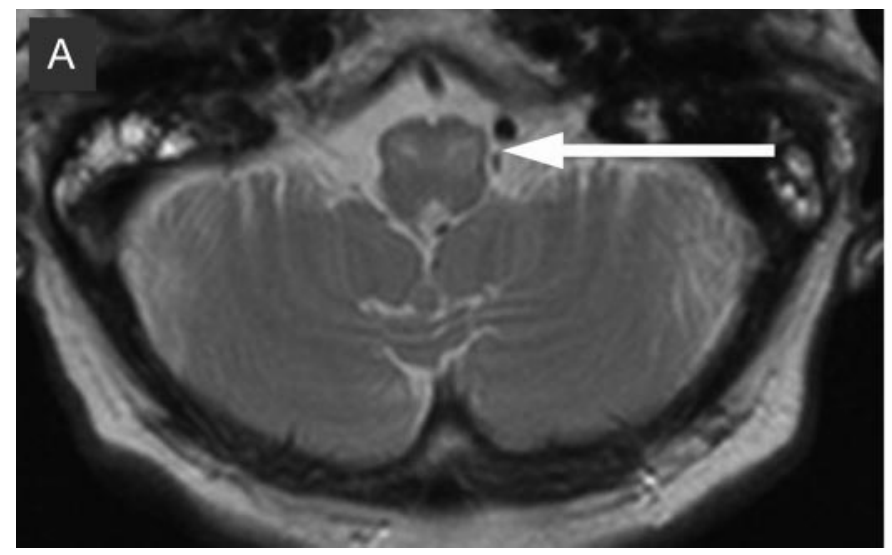

A 76-year-old woman presented with symptomatic palatal tremor (SPT) characterized by rhythmic contractions of the levator veli palatini muscle (video on the Neurology ${ }^{\circledR}$ Web site at www.neurology.org). She did not complain of ear clicks. Physical examination revealed bilateral saccadic pursuit, bilateral impaired suppression of the vestibulo-ocular reflex, and autonomic dysfunction. One year later, she developed left Horner syndrome. MRI showed bilateral olivary hypertrophy (figure). Further studies including routine blood tests, serologic tests, paraneoplastic antibodies, CSF, PET$\mathrm{CT}$, and ${ }^{123}$ I-Iodobenzamide-SPECT were negative.

SPT is differentiated from essential palatal tremor (EPT) by 1) the presence of neurologic signs other than palatal tremor, 2) the absence of ear clicks, 3) olivary hypertrophy, and 4) contractions of the levator veli palatini. ${ }^{1,2}$ Etiologies of SPT include cerebrovascular disease, trauma, multiple sclerosis, tumors, neurodegenerative diseases, and other causes. In contrast to SPT, EPT is caused by contractions of the tensor veli palatini. Patients frequently complain about ear clicks. There is no identifiable etiology, no additional neurologic deficit, and the MRI is unremarkable. Clinical and laboratory findings in our patient indicated SPT and suggested an underlying neurodegenerative disease. ${ }^{3}$

\section{REFERENCES}

1. Deuschl G, Mischke G, Schenck E, Schulte-Monting J, Lucking CH. Symptomatic and essential rhythmic palatal myoclonus. Brain 1990;113:1645-1672.

2. Deuschl G, Wilms H. Clinical spectrum and physiology of palatal tremor. Mov Disord 2002;17 suppl 2:S63-S66.

3. Kulkarni PK, Muthane UB, Taly AB, Jayakumar PN, Shetty R, Swamy HS. Palatal tremor, progressive multiple cranial nerve palsies, and cerebellar ataxia: a case report and review of literature of palatal tremors in neurodegenerative disease. Mov Disord 1999;14:689-693.
Supplemental data at www.neurology.org
From the Department of Neurology (C.F., C.J.P.), Department of Otolaryngology (M.D.J.), and Institute of Integrative Anatomy (T.J.), CharitéUniversitätsmedizin Berlin, Germany.

Disclosure: Dr. Finke receives research support from the Federal Ministry of Education and Research. Dr. Jumah and Dr. Jöns report no disclosures. Dr. Ploner receives research support from the Federal Ministry of Education and Research, Forschungsförderung of the Charite Berlin, and the Deutsche Forschungsgemeinschaft (German Research Foundation). 


\section{Neurology}

\section{Teaching Video NeuroImages: An endoscopic view of symptomatic palatal tremor}

Carsten Finke, Masen Dirk Jumah, Thomas Jöns, et al.

Neurology 2010;74;e16

DOI 10.1212/WNL.0b013e3181ce88e3

\section{This information is current as of February 1, 2010}

\section{Updated Information \&}

Services

Supplementary Material

References

Subspecialty Collections

Permissions \& Licensing

Reprints including high resolution figures, can be found at:

http://n.neurology.org/content/74/5/e16.full

Supplementary material can be found at:

http://n.neurology.org/content/suppl/2010/01/31/74.5.e16.DC1

This article cites 3 articles, 0 of which you can access for free at: http://n.neurology.org/content/74/5/e16.full\#ref-list-1

This article, along with others on similar topics, appears in the following collection(s):

Clinical neurology examination

http://n.neurology.org/cgi/collection/clinical_neurology_examination

Myoclonus

http://n.neurology.org/cgi/collection/myoclonus

Tinnitus

http://n.neurology.org/cgi/collection/tinnitus

Tremor

http://n.neurology.org/cgi/collection/tremor

Information about reproducing this article in parts (figures,tables) or in its entirety can be found online at:

http://www.neurology.org/about/about_the_journal\#permissions

Information about ordering reprints can be found online:

http://n.neurology.org/subscribers/advertise

Neurology ${ }^{\circledR}$ is the official journal of the American Academy of Neurology. Published continuously since 1951, it is now a weekly with 48 issues per year. Copyright . All rights reserved. Print ISSN: 0028-3878. Online ISSN: 1526-632X.

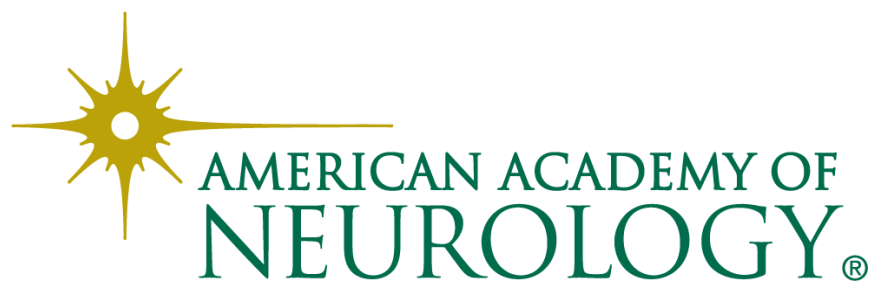

